\title{
PRODUCTION OF HIGH NUTRITIONAL VALUE COOKIES FROM BROKEN RICE SUPPLEMENTED WITH SWEET LUPIN FLOUR
}

\author{
AMERA T. MOHAMMED
}

Crop Tech. Res., Food Tech. Res. Inst., ARC, Giza, Egypt.

(Manuscript received 20 February 2017 )

\begin{abstract}
$\mathrm{T}$ he objective of the current study was to produce high nutritional value gluten-free cookies from broken rice and sweet lupin flour. Rice flour was replaced with $20 \%, 40 \%$, $60 \%$ and $80 \%$ sweet lupin flour. Sensory evaluation, physical properties and chemical composition were determined to assess the quality of produced cookies. The results indicated that the incorporation up to $40 \%$ sweet lupin flour into cookies had the highest score in taste and overall acceptability. Physical properties of cookies replaced with $40 \%$ sweet lupin showed increased thickness with a reduction in diameter and spread ratio. Protein, $\mathrm{Fe}, \mathrm{Ca}, \mathrm{Zn}$, In-vitro protein digestibility (IVPD), total essential amino acids, chemical score and biological value were increased in sweet lupin cookies meanwhile, total carbohydrate content was lower compared to control. Therefore, it could be recommended the use of sweet lupin flour for enhancement the nutritional value of bakery products.

Key words: sweet Lupin flour, rice flour, free- gluten cookies, Chemical composition, Sensory evaluation, Physical properties.
\end{abstract}

\section{INTRODUCTION}

Sweet lupin seeds are good sours of protein, especially lysine but its poor in the sulfur-containing amino acids-methionine, cystein and theronine Abdelrahman, (2014). Lupin flour (LF) is widely considered an excellent raw material for supplementing different food products owing to its high protein content (Kohajdova et al. 2011) .Other naturally components of lupin seeds are oligosaccharides, especially raffinose, stachyose, and verbascose, which are contributory factors to flatulence, (diarrhea, nausea) to many consumers Ramadan, (2012).

Broken rice is a by-product produced during rice milling and polishing. Rice flour is used in many gluten-free formulas. It is available in several different textures, from regular to fine grinds. Broken rice flour had $7.95 \%$ protein, $0.30 \%$ fat, $0.42 \%$ crude fiber, $0.80 \%$ ash, and $90.53 \%$ carbohydrate Ola et al, (2015).

Cookies are baked products, which are considered the most desirable products for all ages due to their low manufacturing cost, convenience, long shelf life and good eating quality. Moreover, cookies could be used as a vehicle to deliver essential nutrients to people Maghaydah et al , (2013). 
Gluten-Free foods have attracted much research interest especially, with rising number of patients with gluten sensitivity and celiac disease. In addition to, the rapid change in consumer life style, where gluten-free diet is also associated with weight management and overall health . Rice, corn, amaranth, cassava, soybean and peanut, gums and hydrocolloids, enzymes, soybean proteins, egg white have been used to mimic viscoelastic properties of gluten in gluten-free cereal products in order to improve quality, structure, mouthfeel, acceptability and shelf life (Korus etal.2006). Lupin flour does not contain gluten thus it is sometimes used as functional ingredient in gluten- free foods with improved nutritional quality at a comparatively lower cost (Kohajdova et al. 2011). A balance of nutrients may be obtained by including cereals and pulses in our diets. Such these diets supply a large proportion of our energy needed, carbohydrate, protein, dietary fiber, amino acids and minerals.

Therefore, the present research work aimed to determine and evaluate the effect of the partial replacement of rice flour with varying levels of sweet lupin flour on the physical properties, quality and consumer acceptability of cookies for finding maximum incorporation of lupine flour to improve the nutritional quality of gluten-free cookies

\section{MATERIALS AND METHODS}

\section{Materials}

Broken rice was obtained from Sakha Research Station Agricultural Research Center, Kafrel-Shiekh, Egypt. Broken rice was grounded into flour to obtain particles around $0.45 \mathrm{~mm}$. Sweet lupin was purchased from local market, Giza, Egypt, and milled into flour after soaking to obtain particles around $0.45 \mathrm{~mm}$, then kept in polyethylene bags at refrigerator till using. Powdered sugar, shortening, baking powder, salt, vanilla and milk were purchased from local market, Giza, Egypt. Standard, sucrose, stachyose and raffinose were obtained from Sigma Co. Sanit Louis, Missori, U.S.A.

\section{preparation of Lupin flour}

Sweet lupin seeds were cleaned from impurities then washed with tape water and soaked in water for $24 \mathrm{~h}$ then firmly dehulled manually and finally dried in oven at $60^{\circ} \mathrm{C}$. The dried lupin seeds were ground into flour to get particles around $0.45 \mathrm{~mm}$.

\section{Determination of raffinose family and sucrose}

Raffinose family and sucrose of cookies was evaluated according to the method described by Zielinski et al, (2014). Sample (1g) was diluted 1:10 (v/v) with ultra purified water and then filtered through $0.22 \mu \mathrm{m}$ filter membrane. $1.5 \mathrm{ml}$ of these solutions was placed in vials for injection into HPLC Agilant packared (series 1100) equipped with auto sampling injector, IR detector. The column temperature was 
maintained at $35 \mathrm{c}^{\circ}$. The column was used Aminex- carbohydrate HPX-87C, $300 \mathrm{~mm}$ $\times 7.8 \mathrm{~mm}$.

\section{Production of cookies}

\section{Cookies formula and Ingredients}

The cookies dough was prepared according to the formula presented in Table 1., which described by Obeidat etal. (2012). Rice cookies supplemented with lupin flour at different levels of $20 \%, 40,60$ and $80 \%$. Control cookies was produced from (100\% Rice flour).

Table 1. Formula of Rice cookies supplemented with lupin flour

\begin{tabular}{|l|c|c|c|c|c|c|c|c|}
\hline & Ingredients \\
Treatment & $\begin{array}{c}\text { Rice } \\
\text { flour }\end{array}$ & $\begin{array}{c}\text { Lupin } \\
\text { flour }\end{array}$ & $\begin{array}{c}\text { powdered } \\
\text { Sugar }\end{array}$ & shortening & Baking & milk & salt & Vanillia \\
\hline $\mathrm{R}$ & 100 & - & 35 & 36 & 3 & 10 & 1 & 1 \\
\hline $\mathrm{RL}_{1}$ & 80 & 20 & 35 & 36 & 3 & 10 & 1 & 1 \\
\hline $\mathrm{RL}_{2}$ & 60 & 40 & 35 & 36 & 3 & 10 & 1 & 1 \\
\hline $\mathrm{RL}_{3}$ & 40 & 60 & 35 & 36 & 3 & 10 & 1 & 1 \\
\hline $\mathrm{RL}_{4}$ & 20 & 80 & 35 & 36 & 3 & 10 & 1 & 1 \\
\hline
\end{tabular}

$\mathrm{R}=$ control rice flour $\quad \mathrm{RL}_{1,2,3,4}=$ Rice flour supplemented with $20,40,60$ and $80 \%$ Lupin flour respectively.

\section{Dough preparation}

Powdered sugar and shortening were mixed for $2 \mathrm{~min}$ at speed four using a mixer. The dry ingredients were weighed and mixed with milk for $3 \mathrm{~min}$ at speed 3 to get cookies dough. Then, it was sheeted to a thickness of about $5 \mathrm{~mm}$, the sheeted dough was cut into round shape using a $35 \mathrm{~mm}$ diameter. The cookies dough was baked at $180 \mathrm{C}^{\circ}$ for 12-15 min. Cookies were kept at room temperature for 8-10 minutes after baking until sensory evaluation, Obeidat et al. (2012). The reset of cookies were kept in polyethylene bags at refrigerator until physical and chemical analyses.

\section{Analytical methods}

Crude protein, crude fat, ash, crude fiber and moisture contents were analyzed in rice, lupin flours and cookies according to the procedures described in AOAC, (2005). Total carbohydrates was calculated by difference. Minerals content were determined

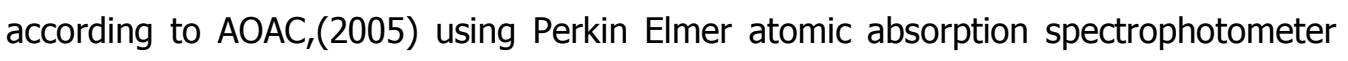
model 3300 (USA).

\section{Sensory Evaluation of cookies}

Sensory characteristics of cookies were evaluated according to the method described by Chinma et al, (2012) which carried out by panel of ten experienced guides from the staff of the Food Tech. Res. Institute, Agric., Res. Center, Giza, 
Egypt. Assigning scores for various qualities attributes such as: color, taste, texture, aroma and overall acceptability on a nine- point hedonic scale (1= disliked extremely, to 9 = like extremely).

\section{Physical characteristics of cookies}

Cookies diameter, thickness, spread ratio were measured according to AACC (2000). The diameter (D) was measured by placing six cookies edge to edge to get an average diameter in millimeters. The Thickness $(T)$ was measured by stacking six cookies on top of one another and measuring them to get the average in millimeters. The Spread ratio was determined by dividing the diameter out thickness.

\section{Caloric value of the cookies}

Calories of the cookies were calculated by James,(1995) as follows: caloric value $(\mathrm{Kca} / 100 \mathrm{~g})=4($ protein $)+4($ carbohydrate $)+9($ fate $)$

\section{Determination of In vitro Protein Digestibility (IVPD)}

The IVPD of the cookies was determined according to the method of Akeson and Stahmann (1964). After enzymatic digestion of samples with pepsin $\left(37^{\circ} \mathrm{C} / 3 \mathrm{~h}\right)$ and pancreatin $\left(37^{\circ} \mathrm{C} / 24 \mathrm{~h}\right)$, the protein in the resultant supernatant was estimated using the Kjeldahl method according to AOAC, ( 2005). The percentage of protein digestibility was calculated by the ratio of protein in supernatant to protein in sample as the following equation:

protein digestabilty $\%=N$ in supernatant $-N$ in Blank $/ N$ in sample $\times 100$

$$
\mathrm{N}=\text { Nitrogen }
$$

\section{Determination of Amino acids Profile of cookies}

Amino acids content was determined using amino acids analyzer Biochrom 30 using the instruction manual according to AOAC, (2005).

\section{Biological value of Cookies}

Biological value of the cookies were calculated according to Eggam et.al, (1979) as follows:

$$
\text { Bilogical value } \%=39.55+8.89 \times l y \sin (g / 100 g \text { protein })
$$

\section{Chemical score of cookies}

Chemical score were calculated according to FAO/WHO (2007) as follows:

Chemical score $\%=\frac{\text { Essential amino acid of crude protein }}{\text { Essential amino acid of FAO/WHO }} \times 100$ 


\section{Statistical Analysis}

The obtained data were exposed to analysis of variance (ANOVA). Duncan is multiple range tests at $(P \leq 0.05)$ level was used to compare between means values. Waller and Duncan, (1969).

\section{RESULTS AND DISCUSSION}

\section{The rafinose family and sucrose of lupin flour}

Raffinose, stachyose and sucrose percentage were analyzed in Lupin flour before and after soaking and the results are shown in Table 2 .Results indicated that the Raffinose reduced by $37.5 \%$, Stachyose by $7.08 \%$ and sucrose by $30.62 \%$ after soaking and dehhulling. In yellow lupin seeds the content of raffinose $1.23 \mathrm{~g} / 100 \mathrm{~g}$, stachyose $5.14 \mathrm{~g} / 100 \mathrm{~g}$, sucrose $1.54 \mathrm{~g} / 100 \mathrm{~g}$ and verbascose $2.90 \mathrm{~g} / 100 \mathrm{~g}$ Sobotk etal.,(2013) .Stachyose $(5.87 \mathrm{~g} / 100 \mathrm{~g})$ was the most abundant oligosaccharide in lupin, followed by sucrose $(3.23 \mathrm{~g} / 100 \mathrm{~g})$, verbascose $(1.37 \mathrm{~g} / 100 \mathrm{~g})$ and raffinose (1.33g/100g) Bhardwaj and Hamama , (2013).

Table 2 . The raffinose family and sucrose of lupin flour (\%)

\begin{tabular}{|c|c|c|c|}
\hline Analysis & Raffinose & Stachyose & Sucrose \\
\hline LBS & 1.12 & 5.22 & 1.60 \\
\hline LAS & 0.70 & 4.85 & 1.11 \\
\hline Reduction \% & 37.5 & 7.08 & 30.62 \\
\hline
\end{tabular}

LBS= Lupin before soaking

LAS=Lupin after soaking and dehulling

\section{Chemical Composition of lupin and rice flour}

Data in Table 3.showed that the lupin flour contained higher level of crude protein, crude fat, crude fiber and lower level of total carbohydrates compared to rice flour that distinguished by the highest value of total carbohydrates. Our present findings are in accordance with those of Abdelrahman (2014) who indicated that \% protein, fat and ash contents of lupin flour were $(38.6 ; 9.49$ and 3.41$)$, respectively. The moisture content of Lupin flour was (8.7g/100g) Yorgancilar and Bilgicli (2014).Total carbohydrate of lupin flour was $36.76 \%$ Maghaydah et al,(2013). Rice flour had high amount of total carbohydrate $90.14 \%$, protein $7.72 \%$ (Abdel-Haleem, and Hafez, (2015). From the same Table, lupin flour was a rich source of $\mathrm{Mg}$ and $\mathrm{Ca}$; while $\mathrm{Fe}$ and $\mathrm{Zn}$ were found in lowest values. Meanwhile the broken rice flour contained 28.02 
$\mathrm{Mg}, 10.55 \mathrm{Ca}, 0.91 \mathrm{Fe}$ and $0.29 \mathrm{Zn} \mathrm{mg} / 100 \mathrm{~g}$, respectively. These result are in accordance with those reported by Yorgancilar and Bilgicli,( 2014) .

Table 3. Chemical Composition $(\mathrm{g} / 100 \mathrm{~g})$ and Minerals Content $(\mathrm{mg} / 100 \mathrm{~g})$ of lupin and broken Rice flour on dry wieght

\begin{tabular}{|c|c|c|c|c|c|c|c|c|c|c|}
\hline Treatment & Moisture & Ash & Protein & $\begin{array}{c}\text { Crude } \\
\text { fat } \\
\end{array}$ & $\begin{array}{l}\text { Crude } \\
\text { fiber }\end{array}$ & T.C C $^{* *}$ & $\mathrm{Mg}$ & $\mathrm{Ca}$ & $\mathrm{Fe}$ & $\mathrm{Zn}$ \\
\hline Lupine flour & $\begin{array}{l}8.76^{\mathrm{b}} \\
\pm 0.03 \\
\end{array}$ & $\begin{array}{l}3.21^{\mathrm{a}} \\
\pm 0.03 \\
\end{array}$ & $\begin{array}{l}39.19^{\mathrm{a}} \\
\pm 0.01 \\
\end{array}$ & $\begin{array}{r}9.98^{\mathrm{a}} \\
\pm 0.05 \\
\end{array}$ & $\begin{array}{l}5.64^{\mathrm{a}} \\
\pm 0.04 \\
\end{array}$ & $\begin{array}{l}41.98^{b} \\
\pm 0.05\end{array}$ & $\begin{array}{r}110.33^{\mathrm{a}} \\
\pm 3.21 \\
\end{array}$ & $\begin{array}{l}290^{\mathrm{a}} \\
\pm 3.0\end{array}$ & $\begin{array}{l}5.43^{a} \\
\pm 0.04 \\
\end{array}$ & $\begin{array}{l}4.95^{a} \\
\pm 0.05\end{array}$ \\
\hline $\begin{array}{c}\text { Broken Rice } \\
\text { flour }\end{array}$ & $\begin{array}{l}9.01^{\mathrm{a}} \\
\pm 0.01 \\
\end{array}$ & $\begin{array}{l}0.39^{\mathrm{b}} \\
\pm 0.04 \\
\end{array}$ & $\begin{array}{l}8.15^{\mathrm{b}} \\
\pm 0.03 \\
\end{array}$ & $\begin{array}{r}0.32^{\mathrm{b}} \\
\pm 0.02 \\
\end{array}$ & $\begin{array}{l}0.28^{b} \\
\pm 0.05 \\
\end{array}$ & $\begin{array}{l}90.86^{a} \\
\pm 0.04\end{array}$ & $\begin{array}{r}28.02^{\mathrm{b}} \\
\pm 0.03 \\
\end{array}$ & $\begin{array}{l}10.55^{\mathrm{b}} \\
\pm 0.05 \\
\end{array}$ & $\begin{array}{l}0.91^{\mathrm{b}} \\
\pm 0.04 \\
\end{array}$ & $\begin{array}{l}0.29^{\mathrm{b}} \\
\pm 0.02 \\
\end{array}$ \\
\hline
\end{tabular}

T. $\mathrm{C}^{* *}=$ Total carbohydrate calculated by deference Means with different letters are significantly different at $P \leq 0.05$.

\section{Sensory evaluation of cookies}

Sensory evaluation of the studied cookies are outlined in Table 4. It could noticed that addition of lupin flour exhibited a substantial effect on the sensory properties of rice cookies; the sensory scores for color of cookies were improved by the incorporation of lupin flour. The color score of cookies was increased with the increase in lupin flour substitution similar improvements in color of different foods by lupin incorporation have been reported in other studies. Cookies containing lupin flour up to $30 \%$ improved the color score of the cookies Bilgicli and Levent , (2014)

Table 4. Sensory characteristics of cookies

\begin{tabular}{|l|c|c|c|c|c|}
\hline \multicolumn{1}{|c|}{$\begin{array}{c}\text { Color } \\
(9)\end{array}$} & $\begin{array}{c}\text { Taste } \\
(9)\end{array}$ & $\begin{array}{c}\text { Aroma } \\
(9)\end{array}$ & $\begin{array}{c}\text { Texture } \\
(9)\end{array}$ & $\begin{array}{c}\text { Overall } \\
\text { Acceptability } \\
(9)\end{array}$ \\
\hline $\mathrm{R}$ & $8.24^{\mathrm{d}} \pm 0.24$ & $8.40^{\mathrm{a}} \pm 0.84$ & $8.50^{\mathrm{a}} \pm 0.70$ & $8.30^{\mathrm{a}} \pm 1.05$ & $8.42^{\mathrm{a}} \pm 0.76$ \\
\hline $\mathrm{RL}_{1}$ & $8.52^{\mathrm{c}} \pm 0.10$ & $7.40^{\mathrm{ab}} \pm 0.87$ & $8.15^{\mathrm{ab}} \pm 1.0$ & $7.45^{\mathrm{ab}} \pm 0.95$ & $7.80^{\mathrm{ab}} \pm 0.72$ \\
\hline $\mathrm{RL}_{2}$ & $8.71^{\mathrm{b}} \pm 0.12$ & $7.10^{\mathrm{ab}} \pm 1.42$ & $8.05^{\mathrm{ab}} \pm 0.95$ & $7.20^{\mathrm{b}} \pm 1.00$ & $7.83^{\mathrm{ab}} \pm 0.73$ \\
\hline $\mathrm{RL}_{3}$ & $8.87^{\mathrm{a}} \pm 0.07$ & $6.90^{\mathrm{bc}} \pm 1.59$ & $7.70^{\mathrm{ab}} \pm 1.15$ & $6.17^{\mathrm{c}} \pm 1.06$ & $7.39^{\mathrm{bc}} \pm 0.66$ \\
\hline $\mathrm{RL}_{4}$ & $8.97^{\mathrm{a}} \pm 0.03$ & $6.0^{\mathrm{c}} \pm 1.49$ & $7.20^{\mathrm{b}} \pm 1.61$ & $5.5^{\mathrm{c}} \pm 1.10$ & $6.90^{\mathrm{c}} \pm 0.61$ \\
\hline
\end{tabular}

$\mathrm{R}=$ control rice flour Lupin flour respectively. significantly different at $P \leq 0.05$.

Regarding to taste score, results showed that substitution with lupin up to $40 \%$ did not affect significantly taste score. However, significant decrease in taste score was observed at 60 and $80 \%$ substitution levels. It might be due to flavor associated with lupin flour. The texture decreased significantly with increase percentage of lupin except $20 \%$ substitution level. This may be due to texture hardness caused by high 
protein and dietary fiber contents of lupin flour when added at higher levels. Fibers sourced from apple, lemon, when added at $\geq 15 \%$ levels caused a reduction in sensory scores for texture of cookies (Jayasena and Nasar, 2011).

Overall acceptability scores provide a general acceptability of the product based on all of the sensory parameters. Cookies made from substituted rice flour with 20 and $40 \%$ lupin showed no significant differences in all over all acceptability relative to control.

\section{Physical Characteristics of Cookies}

Physical Characteristics are presented in Table 5. Results showed that the highest diameter, spread ratio and the smallest thickness was observed in Control . Cookies supplemented with $40 \%$ lupin flour showed increased in thickness with a reduction in diameter and spread ratio. The data are in good agreement with Maghaydah et al, (2013), Chinma et al, (2012) found that the addition of high protein flours sources causes negative correlation on the cookies diameter and spread.

Table 5. Physical characteristics of cookies

\begin{tabular}{|l|l|l|l|}
\hline Treatment & Diameter(mm) & Thickness (mm) & $\begin{array}{c}\text { Spread ratio } \\
(\mathrm{D} / \mathrm{T})\end{array}$ \\
\hline $\mathrm{R}$ & $34.48^{\mathrm{a}} \pm 0.05$ & $6.12^{\mathrm{b}} \pm 0.01$ & $5.63^{\mathrm{a}} \pm 0.04$ \\
\hline $\mathrm{RL}_{2}$ & $34.21^{\mathrm{b}} \pm 0.03$ & $6.34^{\mathrm{a}} \pm 0.01$ & $5.39^{\mathrm{b}} \pm 0.03$ \\
\hline
\end{tabular}

$\mathrm{R}=$ control rice flour $\quad \mathrm{RL}_{2}=$ Rice flour supplemented with $40 \%$ Lupin flour values are means $(n=6) \pm S D \&$ Means with different letters are significantly different at $P \leq 0.05$

\section{Chemical Composition and minerals content of Cookies}

The data in Table 6. revealed that the supplementation with $40 \%$ lupin flour in rice cookies $\left(R L_{2}\right)$ decreased significantly in the total carbohydrates while increased ash, crude fiber, crude protein, crude fat, $\mathrm{Mg}, \mathrm{Zn}, \mathrm{Ca}$, and Fe compared to control ( $\mathrm{R}$ ). The increase in ash, crude fiber, crude protein and crude fat in $R L_{2}$ may be attributed to addition effect by lupin flour to the complementation of rice flour with lupin flour that contain higher amount of crude protein, ash and crude fiber. Lupin flour at $30 \%$ in cookies formulation caused an increment in protein content up two times and improved minerals ( $\mathrm{Mg}, \mathrm{Zn}, \mathrm{Ca}$ and $\mathrm{Fe}$ ) compared to control cookies Bilgicli and Levent, (2014). Considering to the method of processing, before prepare lupin flour (soaking and dehulling), these processing methods increase the protein content. Increment in protein content after soaking was also observed by Hassan et al., (2005). 
Table 6. Chemical Composition $(\mathrm{g} / 100 \mathrm{~g})$ and Mineral Contents $(\mathrm{mg} / 100 \mathrm{~g})$ of Cookies on dry weight.

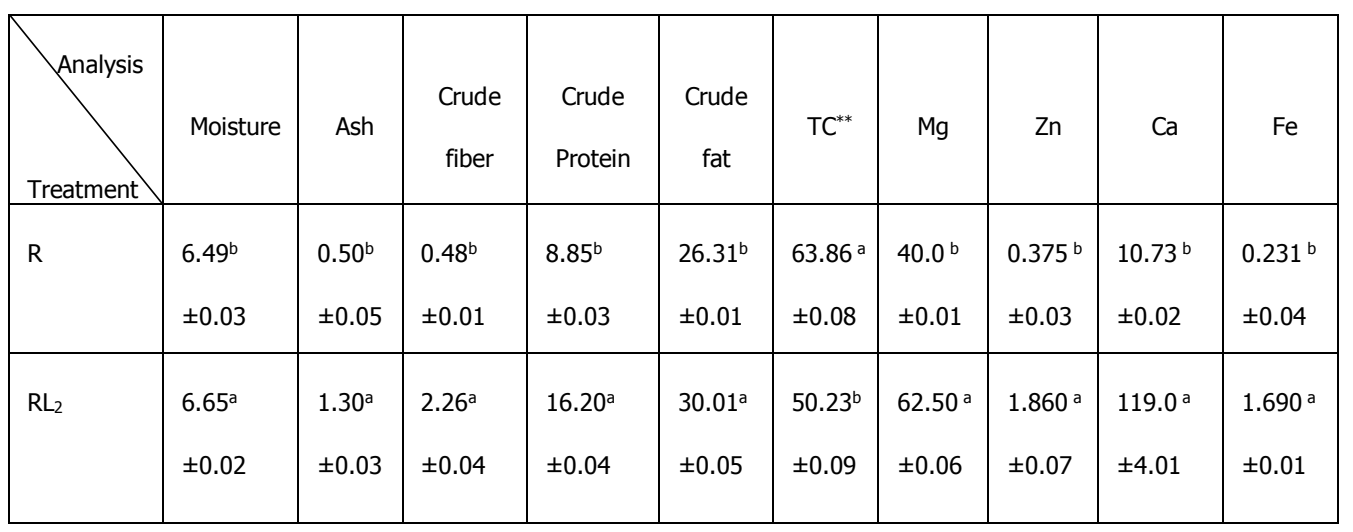

$\mathrm{R}=$ control rice flour $\quad \mathrm{RL}_{2}=$ Rice flour supplemented with $40 \%$ Lupin $\quad{\mathrm{T} . \mathrm{C}^{* *}=\text { Total }}^{*}$ carbohydrate calculated by deference values are means $(n=3) \pm S D$ \& Means with different letters are significantly different at $P \leq 0.05$

\section{Nutritional Quality of Cookies}

Table 7. Represents the nutritional quality of cookies. From calculated data, it could be noticed that the highest accepted cookies $\left(R_{2}\right)$ had higher value of total calories than control (R). RL2, R will provide $26 \%, 25 \%$ respectively, from the DRI of energy for female aged 9-13 year (calculated as $2071 \mathrm{Kcal} /$ day). Moreover, $24 \%, 23 \%$ respectively, from the DRI of energy (calculated as $2279 \mathrm{Kcal} /$ day) for male aged 9-13 year. Each $100 \mathrm{~g}$ ( $R$ and RL2 ) cookies will provide 3\%, 21\% for $\mathrm{Fe} ; 5 \%, 23 \%$ for $\mathrm{Zn}$ and $0.8 \%, 9 \% \mathrm{Ca}$, respectively based on ( $8 \mathrm{mg} /$ day for Fe, Zn and $1300 \mathrm{mg}$ /day for $\mathrm{Ca}$ ) from the DRI for male and female aged 9 - $13 \mathrm{y}$. From the abovementioned data about the nutritional quality, it could be demonstrated that the $\mathrm{RL}_{2}$ cookies had reasonable amounts of the required nutrients particularly energy, $\mathrm{Fe}, \mathrm{Ca}$ and $\mathrm{Zn}$. In vitro Protein digestibility (IVPD) is an important factor for evaluation of protein quality as well as an indicator for protein bioavailability in food Chinma et al.,(2011).

Table 7. Nutritional Quality of Cookies

\begin{tabular}{|l|c|c|c|c|c|c|c|c|}
\hline Analysis & $\begin{array}{c}\text { Crude potein } \\
\mathrm{kcal}\end{array}$ & $\begin{array}{c}\mathrm{TC}^{* *} \\
\mathrm{kcal}\end{array}$ & $\begin{array}{c}\text { Crude fat } \\
\mathrm{kcal}\end{array}$ & $\begin{array}{c}\text { Caloric value } \\
\mathrm{Kca} / 100 \mathrm{~g}\end{array}$ & $\begin{array}{c}\mathrm{Fe} \\
\mathrm{mg} / 100 \mathrm{~g}\end{array}$ & $\begin{array}{c}\mathrm{Zn} \\
\mathrm{mg} / 100 \mathrm{~g}\end{array}$ & $\begin{array}{c}\text { Ca } \\
\mathrm{mg} / 100 \mathrm{~g}\end{array}$ & $\begin{array}{c}\text { IVPD } \\
\%\end{array}$ \\
\hline $\mathrm{R}$ & $\begin{array}{c}35.4^{\mathrm{b}} \\
\pm 0.14\end{array}$ & $\begin{array}{c}255.44^{\mathrm{a}} \\
\pm 0.33\end{array}$ & $\begin{array}{c}236.79^{\mathrm{b}} \\
\pm 0.09\end{array}$ & $\begin{array}{c}527.63^{\mathrm{b}} \\
\pm 0.27\end{array}$ & $\begin{array}{c}0.231^{\mathrm{b}} \\
\pm 0.04\end{array}$ & $\begin{array}{c}0.375^{\mathrm{b}} \\
\pm 0.03\end{array}$ & $\begin{array}{c}10.73^{\mathrm{b}} \\
\pm 0.02\end{array}$ & $\begin{array}{c}60.11^{\mathrm{b}} \\
\pm 0.09\end{array}$ \\
\hline $\mathrm{RL}_{2}$ & $\begin{array}{c}20.80^{\mathrm{a}} \\
\pm 0.18\end{array}$ & $\begin{array}{c}20.92^{\mathrm{b}} \\
\pm 0.36\end{array}$ & $\begin{array}{c}270.09^{\mathrm{a}} \\
\pm 0.05\end{array}$ & $\begin{array}{c}535.81^{\mathrm{a}} \\
\pm 0.31\end{array}$ & $\begin{array}{c}1.690^{\mathrm{a}} \\
\pm 0.01^{2}\end{array}$ & $\begin{array}{c}1.860^{\mathrm{a}} \\
\pm 0.07\end{array}$ & $\begin{array}{c}119.0^{\mathrm{a}} \\
\pm 4.01\end{array}$ & $\begin{array}{c}72.83^{\mathrm{a}} \\
\pm 0.27\end{array}$ \\
\hline
\end{tabular}

$\mathrm{R}=$ control rice flour $\quad \mathrm{RL}_{2}=$ Rice flour supplemented with $40 \%$ Lupine flour

$(\mathrm{IVPD})=$ In vitro Protein digestibility $\quad \mathrm{T}^{*} \mathrm{C}^{* *}=$ Total carbohydrate calculated by deference values are means $(n=3) \pm S D$ \& Means with different letters are significantly different at $P \leq 0.05$ 
Data from Table7. showed that supplementation with $40 \%$ lupin flour increased IVPD compared to control. IVPD were $72.83 \%$ and $60.11 \%$ for $\mathrm{RL}_{2}$ and $\mathrm{R}$, respectively. Guemes-Vera etal.( 2012) who reviewed that in vitro protein digestibility of lupin flour ranged from (78.58-82.72\%). Protein digestibility of rice was $89 \%$ Emara, (2015). Hassan et al. (2005) estimated the in vitro protein digestibility of lupin seed ranged $72-74 \%$ and Processing methods (soaking, cooking, dehulling) of lupin seeds improved protein digestibility. Considering the method of processing, before prepare lupin flour (soaking and dehulling), these processing methods increased the IVPD.

\section{Amino acids profile of cookies}

Table 8. Amino acids, chemical score and Biological value

\begin{tabular}{|c|c|c|c|c|c|c|c|}
\hline \multirow[b]{3}{*}{ EAA } & \multicolumn{3}{|c|}{ Amino acids $\%$} & & & & \\
\hline & \multicolumn{3}{|c|}{$\mathrm{R}$} & \multicolumn{3}{|c|}{$\mathrm{RL}_{2}$} & \multirow[b]{2}{*}{$\begin{array}{c}* \mathrm{FAO} / \mathrm{W} \\
\mathrm{HO}\end{array}$} \\
\hline & $\begin{array}{c}\text { amino } \\
\text { acid } \\
\mathrm{g} / 100 \\
\text { sample } \\
\end{array}$ & $\begin{array}{c}\text { amino } \\
\text { acid } \\
\mathrm{g} / 100 \\
\text { proteine }\end{array}$ & $\begin{array}{l}\text { Chemical } \\
\text { score \% }\end{array}$ & $\begin{array}{c}\text { amino } \\
\text { acid } \\
\text { g/100 } \\
\text { sample }\end{array}$ & $\begin{array}{l}\text { amino } \\
\text { acid } \\
\mathrm{g} / 100 \\
\text { proteine }\end{array}$ & $\begin{array}{l}\text { Chemical } \\
\text { score \% }\end{array}$ & \\
\hline Leucine & 0.55 & 6.21 & 94.10 & 1.04 & 6.42 & 97.27 & 6.6 \\
\hline Valine & 0.42 & 4.74 & 135.43 & 0.67 & 4.14 & 118.29 & 3.5 \\
\hline Lysine & 0.29 & 3.27 & 64.13 & 1.01 & 6.23 & 107.41 & 5.8 \\
\hline Isolucine & 0.27 & 3.05 & 108.92 & 0.66 & 4.07 & 145.36 & 2.8 \\
\hline Phenylalanin & 0.41 & 4.63 & 73.49 & 0.64 & 3.95 & 62.70 & 6.3 \\
\hline Theronine & 0.27 & 3.05 & 89.71 & 0.51 & 3.15 & 92.65 & 3.4 \\
\hline Methonine & 0.25 & 2.82 & 112.8 & 0.19 & 1.17 & 46.8 & 2.5 \\
\hline Total E.A.A & 2.46 & 27.77 & 678.58 & 4.72 & 29.13 & 670.48 & 30.9 \\
\hline \multicolumn{8}{|l|}{ Non -E.A.A } \\
\hline Histidine & 0.18 & 2.03 & & 0.35 & 2.16 & & \\
\hline Argnine & 0.58 & 6.55 & - & 1.26 & 7.80 & - & - \\
\hline Serine & 0.38 & 4.30 & - & 0.66 & 4.07 & - & \\
\hline Tyrosine & 0.38 & 4.30 & - & 0.68 & 4.20 & - & - \\
\hline Aspartic & 0.61 & 6.89 & & 1.34 & 8.30 & & \\
\hline Glutamic & 1.32 & 14.92 & & 2.67 & 16.48 & & \\
\hline proline & 0.41 & 4.63 & & 0.64 & 3.95 & & \\
\hline Glycine & 0.31 & 3.50 & & 0.53 & 3.27 & & \\
\hline Alanin & 0.39 & 4.41 & & 0.57 & 3.52 & & \\
\hline Cysteine & 0.18 & 2.03 & - & 0.30 & 1.85 & - & - \\
\hline Total Non -E.A.A & 4.74 & 53.56 & & 9 & 55.6 & - & - \\
\hline Limiting aminoacids & & & Lysine & & & Methonine & \\
\hline Biological value & - & 68.62 & & - & 94.93 & - & \\
\hline
\end{tabular}

$\mathrm{R}=$ control rice flour $\quad \mathrm{RL}_{2}=$ Rice flour supplemented with $40 \%$ Lupine flour

$\mathrm{EAA}=$ essential amino acid $* \mathrm{FAO} / \mathrm{WHO}(2007)$ 
The amino acids of food product is an important of protein quality. The essential amino acids are necessary for tissue maintenance and required for growth of children. Table 8. Showed that the Essential amino acids (EAA) of accepted sample $\left(R L_{2}\right)$ contained higher amount of leucine, lysine, Isolucine and theronine than those in (R) which contained high amount of valine, phenyl alanine and methonin. Our present findings are in line with Abdelrahman, (2014) who stated that lupin flour was higher in (lysine, theronine and isolucine ). Yorgancilar and Bilgicili , (2014) stated that all essential amino acids were increased except methonine in sweet lupin seeds. Rice protein contains $5.87 \%$ valine, $2.54 \%$ histidine and $2.25 \%$ methonine (USDA, 2011). It could be noticed that, the total EAA and total non-EAA were highest amount in RL2 than $R$. From the same table showed that the Limiting amino acids were lysine for $(R)$ and Methonine for RL2. lupin protein content high amount of lysine and low amount of sulfur amino acids (methonine and cystein Abdelrahman, (2014).On other hand the biological value increased in $\mathrm{RL}_{2}$ than $\mathrm{R}$ (94.93 and $68.62 \%$ ), respectively. Chemical score of $\mathrm{RL}_{2}$ were highest value concerning, Isolucine, lysine, leucine and theronine mean while $\mathrm{R}$ were highest value for Valine, and methonine (Table 8 ). This may be due to the effect of lupins flour addition. Higher lysine content was associated with increasing in biological value (Kohajdova et al.2011).

\section{CONCLUSION}

This study demonstrated the possibility of incorporating lupin flour into cookies processing up to $40 \%$. This product could be used by celiac patient due to it contain high amount of fiber and provides fewer calories and good source of protein, amino acids, Zn, Fe, Ca. Therefore, substitution of sweet lupin flour into cookies improved sensory characteristic, nutritional value and could be utilized from locally product lupin at small scale industry.

\section{REFERENCES}

1. AACC. 2000. In Approved Methods of American Association of Cereal Chemists, 10th Ed., American Association of Cereal Chemists, St. Paul, M.N.

2. Abdelrahman , R.A. 2014. Influence of chemical properties of wheat - lupine flour Blend on cake quality. American Journal of food science and technology. 2:2, 67-75.

3. Akeson, W.R. and, A. Stahmann. 1964. A Pepsin Pancreatin Digest Index of Protein Quality. Journal of Nutrition, 83, 257-261. 
4. Abdel-Haleem, A.MH. and HH. Hafez. 2015. Production of gluten-free and casein free(GFCF) cupcakes for autistic children. J. of Food and nutritional disorders, 4:3,1-9.

5. AOAC.2005. Official Methods of AOAC 18th Ed., 2005 current through revision I, Basic sensory methods for food Evaluation. IDRC, Ottawa Ontario, Canada.

6. Bhardwaj, H. L. and Hamama A. A. 2013. Cultivar and Growing Location Effects on Fatty Acids, Minerals, and Sugars in Green Seeds of White Lupin (Lupinus albus L.). The Open Horticulture Journal. 6, 1-8.

7. Bilgicli, N. and H. Levent. 2014. Utilization of lupin ( Lupinus albusl.) flour and bran with xylanase enzyme in cookies production .Legume research , 37 (3):264271.

8. Chinma ,C. E.; S. James; H. Imam ; O. B. Ocheme and J. C. Anuonye. 2011. Biscuit making potential of tigernut ( Cyperus esculentus ) and pigeon pea (Cajnus Cajan ) flour blends . Nigerian J. Nutr.Sci. ,32:55-62.

9. Chinma,C.E.; B.D. Igbabul and O.O. Omotayo. 2012. Quality Characteristics of cookies prepared from unripe plantain and defatted sesame flour blends. American Journal of food Technology. 7:7, 398-408.

10. DRI. 2005. Dietary Reference Intakes for Energy, Carbohydrate. Fiber, Fat, Fatty Acids, Cholesterol, Protein, and Amino Acids (Macronutrients). The National Academies Press, Washington DC. www.nap.edu.

11. Eggam, B.O.; E. M. Villegas and S. K. Vasal. 1979. Progress in protein quality of maize . J. Sci., Food Agric., 30:1148-1153.

12. Emara, M. A. H. 2015. Utilization of extrusion technique to produce high nutrition snacks based on cereals and legumes .M.SC. Thesis, Damanhour University, Faculty of Agric. 113pp.

13. FAO/ WHO. 2007. Energy and protein requirement. In Geneva, nutrition report series No.935,

14. Guemes-Vera, N.; J. Martinez-Herrera; J. Hernandez-Chavez; J. Yanez-Fernandez and A. Totosaus. 2012. Comparison of Chemical Composition and Protein Digestibility, Carotenoids, Tanins and Alkaloids Content of Wild Lupinus Varieties Flour. Pakistan Journal of Nutrition 11 (8): 774-780, ISSN 1680-5194.

15. Hassan, A. B.; G. A. Osman and E. E. Babiker. 2005. Effect of domestic processing on anti nutrients and availability of proteins and minerals of lupin (Lupinus termis) seeds. J. Food Technol., 3(2): 255- 262.

16. James, C. S. 1995. General Food Studies. In: Analytical Chemistry of Foods, Blachie Academic and Professional, London, New York, Tokyo, Chapter 6, 135. 
17. Jayasena, V. and S. M. Nasar-Abbas. 2011. Effect of lupin flour incorporation on the physical characteristics of dough and biscuits. Quality Assurance and Safety of Crops and Foods 3:140-147

18. Kohajdova, Z.; J. Karovičova and Štefan Schmidt. 2011. Lupin Composition and Possible Use in Bakery- A Review. Czech J. Food Sci. Vol. 29, No. 3: 203-211

19. Korus, J.; K. Grzelak; K. Achremowicz and R. Sabat. 2006. Influence of prebiotic additions on the quality of gluten-free bread and on the content of inulin and fructooligosaccharides, Food Sci. Technol. Int. 12:489-495.

20. Maghaydah, S.; S. Abdul-hussain ; R. Ajo ; Y. Tawalbeh and N. Elsahory. 2013. Effect of Lupin Flour on Baking Characteristics of Gluten Free Cookies. Advance Journal of Food Science and Technology. 5(5): 600-605.

21. Obeidat, B. A.; S. S. Abdul-Hussain and D. Z.. Al-Omari. 2012. Effect of addition of germinated lupine flour on the physiochemical and organoleptic properties of cookies. J. Food Proc. Preservation, DOI: 10.1111/j.1745-4549.2012.00688.x.

22. Ola, S. I ; Amera ,T. M. and Hayat, H. A, (2015). Quality Characteristics of Rice Biscuits Sweetened with Carob Powder. Middle East J. Appl. Sci., 5(4): 10821090, ISSN 2077-4613

23. Ramadan, E. A. 2012. Effect of Processing and Cooking Methods on the Chemical Composition, Sugars and Phytic acid of Soybeans Food and Public Health. 2(1):11-15

24. Sobotka,W.; S. Maria; B. Jacek and M. Paulius. 2013. The effect of oligosaccharides and alkaloids contained in yellow and blue lupine seeds on feed intake,body weight and fermentation processes in the cecum of rats. Vet. Med. Zoot. T. 63 (85). ISSN 1392-2130.

25. USDA. 2011. United States Department of Agriculture. National Nutrient Database for standard reference release 24.http://www.ars.usda.gov/services/ doc.htm. docid=8964.

26. Waller, W. M. and D. B. Duncan. 1969. A bayes rule for symmetric multiple composition problem. Am. State. Assoc. J. 64:1487-1503.

27. Yorgancilar, M. and N. Bilgicli. 2014. Chemical and nutritional changes in bitter and sweet lupine seeds ( /upinus alpus L.) during bulgur production . J. Food Sci. Technol. 51(7): 1384-1389.

28. Zielinski, AA. F. ; CM.Braga ; IM . Demiate ; FL. Beltrame; A. Nogueira and G. Wosiacki. 2014. Development and optimization of a HLPC-RI method for the determination of major sugars in apple juice and evaluation of the effect of the ripening stage. Food sci. technol. Campinas, 34(1): 38-43. 
انتاج كوكيز مرتفع القيمة الغذائية من دقيق كسرالارز المدعم بدقيق الترمس الحلو

أمبرة طه محمد محمد

$$
\text { معهد بحوث نكنولوجيا الاغذية - مركز البحوث الزراعية - جيزة }
$$

تهذف الدراسة لانتاج كوكيزمرتفع القيمة الغذائية خالى من الجلوتين وذللك باستبدال دقيق

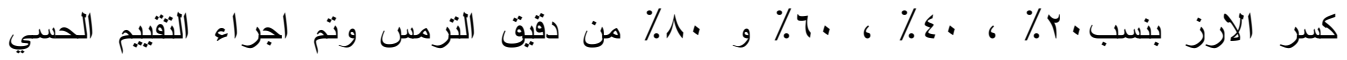
و الخصائص الفيزيائية و الكيميائية للكوكيز واوضحت النتائج ان تدعيم الكوكيز بنسبة ، ــ من دقيق التزمس الحلو سجلت اعلى النتائج من حيث الطعم و القبول العام والخصائص الفيزيائية حيث اوضحت النتائج زيادة فى السمك مع انخفاض القطر كما حدث ارتفاع فى محتوى البرونين والحديد و الزنك و الكالسيوم ومعامل هضم البروتين والاحماض الامينية الاساسية الكلية والقيمة الحيوية بينما حدث انخفاض فى محتوى الكربو هيدرات الكلية بالمقارنة مع العينة الضابطة . وبالتالى يمكن

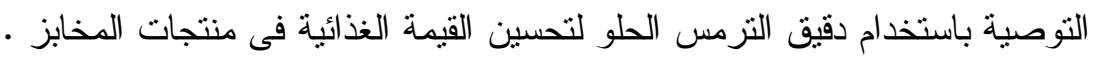

